\author{
SERIES 'PROTEOLYTIC ENZYMES AND AIRWAY DISEASES' \\ Edited by J.A. Nadel and R.A. Stockley \\ Number 1 in this Series
}

\title{
Neutrophil serine proteinases and defensins in chronic obstructive pulmonary disease: effects on pulmonary epithelium
}

\author{
P.S. Hiemstra, S. van Wetering, J. Stolk
}

Neutrophil serine proteinases and defensins in chronic obstructive pulmonary disease: effects on pulmonary epithelium. P.S. Hiemstra, S. van Wetering, J. Stolk. OERS Journals Ltd 1998.

ABSTRACT: Neutrophils have the capacity to accumulate in high numbers in the lung during infection and inflammation. Because they play an important role in host defence against infection, but may also cause tissue injury, these cells are thought to be involved in the pathogenesis of various inflammatory lung disorders, including chronic bronchitis and chronic obstructive pulmonary disease. Neutrophil products that may mediate tissue injury at sites of neutrophil-dominated inflammation include the neutrophil serine proteinases elastase, cathepsin $G$ and proteinase 3 , and the nonenzymatic defensins. One of the targets of the neutrophil is the lung epithelium, and in vitro studies have revealed that both the serine proteinases and neutrophil defensins markedly affect the integrity of the epithelial layer, decrease the frequency of ciliary beat, increase the secretion of mucus, and induce the synthesis of epithelium-derived mediators that may influence the amplification and resolution of neutrophil-dominated inflammation. Both neutrophil elastase and defensins induce the release of the neutrophil chemoattractant chemokine interleukin-8 from respiratory epithelial cells. The $\alpha_{1}$-proteinase inhibitor $\left(\alpha_{1}-\mathrm{PI}\right)$ is a well-characterized inhibitor of neutrophil elastase, that also blocks the cytotoxic and stimulatory activity of defensins towards epithelial cells. The elastase inhibitory activity of $\alpha_{1}-\mathrm{PI}$ is also abrogated by the binding of defensins to this inhibitor. Incubation of epithelial cells with neutrophil defensins in combination with either elastase or cathepsin $G$ resulted in decreased effects on the epithelial cells compared with those observed when the cells were incubated with defensins, elastase or cathepsin G separately.

These results suggest that neutrophil defensins and serine proteinases cause injury and stimulate epithelial cells to produce chemokines that attract more neutrophils to the site of inflammation. The effects of neutrophil defensins and serine proteinases on epithelial cells appear to be restricted by proteinase inhibitors and by inhibitory interactions between these sets of neutrophil granule proteins. Eur Respir J 1998; 12: 1200-1208.

Dept of Pulmonology, Leiden University Medical Center, Leiden, The Netherlands.

Correspondence: P.S. Hiemstra

Dept of Pulmonology

Building 1, C3-P

Leiden University Hospital

P.O. Box 9600

2300 RC Leiden

The Netherlands

Fax: 31715248118

Keywords: Chronic obstructive pulmonary disease

defensins

elastase

epithelium

neutrophils

serine proteinases

Received: November 251997

Accepted after revision December 111997

The studies undertaken in the authors' laboratory cited in this review are supported in part by grants from the Dutch Asthma Foundation (grants no. 87.13 and 93.61) and the European Union (EU Biomed 2 programme, grant no. BMH4, CT96-0152).
Inflammatory processes are thought to play an important role in the pathogenesis of chronic obstructive pulmonary disease (COPD). In these patients increased numbers of inflammatory cells and high levels of inflammatory mediators have been reported in bronchoalveolar lavage (BAL) fluid, sputum (spontaneously produced or induced) and lung tissue. An accumulation of various cell types in the airway lumen and lung tissue has been found to be associated with the development of COPD. These cell types include neutrophils, macrophages, T-lymphocytes, eosinophils and mast cells. The cell type that has been most intensely studied in relation to COPD, and especially in chronic bronchitis and pulmonary emphysema, is the neutrophil. Because of their capacity to cause tissue injury, neutrophils are thought to be involved in a variety of other inflammatory lung disorders, including acute respiratory distress syndrome (ARDS), cystic fibrosis and asthma. The focus of this review is on the role of the neutrophil-derived serine proteinases elastase, cathepsin $\mathrm{G}$ and proteinase 3, and of the nonenzymatic neutrophil defensins in the pathogenesis of COPD. Specifically, the effects of these granule proteins on the pulmonary epithelium are discussed in more detail.

Neutrophils and chronic obstructive pulmonary disease

Based on epidemiological studies, cigarette smoking has been identified as a major risk factor for the development of COPD [1, 2]. Cigarette smoking has been reported to be associated with an increased influx of neutrophils into the lung [3-5], suggesting the involvement of the neutrophil in smoking-induced lung inflammation. Whereas the number of neutrophils in the airway lumen of COPD patients is increased [4-7], there is little evidence for increased numbers of neutrophils in lung tissue $[6,8,9]$. 
In pulmonary emphysema, an inverse relationship between local neutrophil numbers in lung tissue and the extent of microscopic emphysema has even been reported [10]. Lack of evidence that neutrophils accumulate in the lung interstitium in COPD may be explained in part by the observation that neutrophils accumulate in the bronchial epithelium of COPD patients. This was demonstrated in a recent study [11], where the number of neutrophils in the bronchial epithelium was increased in patients with chronic bronchitis associated with airflow obstruction compared to chronic bronchitis without airflow obstruction or controls, while no such differences were observed in the subepithelial zone $[9,11]$.

Whereas there appears to be no consensus on the presence of increased neutrophil numbers in lung tissue from COPD patients, analysis of neutrophil chemoattractants and neutrophil degranulation products in secretions and lung tissue supports a role for the neutrophil in COPD. Firstly, the concentration of the neutrophil chemoattractant chemokine interleukin (IL)-8 in BAL or induced sputum from asymptomatic smokers is higher than that from nonsmokers $[7,12,13]$. Volatile factors in cigarette smoke may be responsible for this increase, because these components cause the release of IL-8 from cultured bronchial epithelial cells in vitro [13]. Higher IL-8 and tumour necrosis factor (TNF)- $\alpha$ concentrations were found in induced sputum obtained from COPD patients than in that from asymptomatic smokers and controls [7]. In addition to IL-8 and possibly other related chemokines that are regulated in a similar fashion, neutrophil degranulation products are indicative of neutrophil involvement in COPD. Increased levels of neutrophil-derived myeloperoxidase in BAL from COPD patients indicate that excessive neutrophil degranulation occurs in vivo $[5,6]$. In the parenchyma of the lung a positive correlation has been reported between the presence of emphysematous lesions and the amount of elastase [14]. Finally increased concentrations of elastase-generated split products of elastin and fibrinogen have been reported in urine and plasma from patients with COPD [15-18] demonstrating in vivo proteolytic activity of released elastase.

The extracellular proteolytic activity of neutrophil serine proteinases such as neutrophil elastase is controlled by proteinase inhibitors. Genetic deficiencies in the production of these inhibitors may result in an imbalance between these inhibitors and neutrophil serine proteinases, and studying the association of such deficiencies with an increased risk for development of COPD has provided further support for the role of neutrophils in the pathogenesis of COPD. A major inhibitor of elastase is $\alpha_{1}$-proteinase inhibitor $\left(\alpha_{1}-\mathrm{PI}\right)$, deficiency of which is an established genetic risk factor for the development of pulmonary emphysema [19-21]. The most extensively studied forms of $\alpha_{1}$-PI deficiency are the complete absence of $\alpha_{1}$-PI production or the synthesis of an aberrant form of $\alpha_{1}$-PI termed the PiZZ phenotype which, as a result of a mutation in the $\alpha_{1}$-PI gene, accumulates intracellularly and is poorly secreted. In addition, KaLSHEKER and MORGAN [22] identified a mutation in an enhancer sequence involved in the regulation of the expression of the $\alpha_{1}$-PI gene. This mutation was found more often in COPD patients than in control subjects and apparently does not affect basal expression of the gene but appears to result in a decreased acute phase response of $\alpha_{1}$-PI production. In addition to
$\alpha_{1}$-PI, deficiencies in the serine proteinase inhibitor $\alpha_{1}$ antichymotrypsin $\left(\alpha_{1}\right.$-ACT) have been found to be associated with COPD [21]. Finally, a recent report described an association with mutations in the gene encoding the locally produced inhibitor of elastase and cathepsin $G$, antileukoprotease (ALP; also known as secretory leukocyte proteinase inhibitor (SLPI) [23]). However, it is not known whether this mutation affects the levels or function of ALP.

A role for neutrophils and neutrophil serine proteinases in the pathogenesis of COPD is not only inferred from patient studies, but also strongly supported by the results of animal models of bronchitis and emphysema. Instillation of neutrophil serine proteinases into the lungs of rodents results in the development of emphysematous lesions $[24,25]$. The same can be achieved by inducing recruitment of neutrophils into the lungs through intratracheal administration of bacterial lipopolysaccharide (LPS) [26] or N-formyl-methionyl-leucyl-phenylalanine (FMLP) [27]. Neutrophil elastase is also likely to be a key mediator in these models of emphysema, because elastase inhibitors prevent the development of emphysematous lesions [28], and these lesions are more pronounced in $\alpha_{1}$-PI deficient mice [27].

\section{Neutrophils, neutrophil mediators and tissue injury}

Neutrophils migrate from the blood vessel lumen into the lung interstitium and airway lumen during infection and inflammation. Adhesion molecules and locally produced chemotactic factors, the expression of which is modulated during infection and inflammation, regulate neutrophil migration into the lung (for recent reviews, see [29, 30]). Neutrophil chemotactic factors include bacterial products, complement split products, lipid mediators and chemokines such as IL-8. IL-8 is a major neutrophil chemoattractant in the lung, as demonstrated by the observation that 75-98\% of the neutrophil chemoattractant activity of purulent sputum obtained from patients with chronic airway inflammation can be inhibited by a neutralizing antibody against IL-8 [31]. Similarly to IL-8, other members of the CXC subfamily of chemokines, including epithelial cellderived neutrophil-activating peptide-78 (ENA-78), growth regulatory gene (Gro)- $\alpha,-\beta,-\gamma$, neutrophil-activating peptide-2 (NAP-2) and granulocyte chemotactic protein-2 (GCP2 ), also attract and activate neutrophils [32, 33]. Among the CXC chemokines, IL- 8 appears to display the highest chemotactic and activating activities towards neutrophils in vitro. However, in vivo, GCP-2 was found to be nearly as effective as IL-8 in inducing local neutrophil accumulation upon injection in rabbit skin [33]. The relative contribution of the various CXC chemokines to neutrophil infiltration into the lung is still largely unknown.

Before entering the tissue, neutrophils must adhere to the endothelium and subsequently migrate through the vessel wall. This process is tightly regulated by adhesion molecules on neutrophils and endothelial cells at sites of inflammation [29, 30]. The first step in the adhesion process is mediated by selectin-ligand interactions, resulting in rolling of neutrophils along the endothelial surface. Chemokines may subsequently activate these rolling neutrophils, resulting in an increase in the avidity of integrins on 
the neutrophil surface. These integrins interact with adhesion molecules such as intracellular adhesion molecule (ICAM)-1 on the endothelial cell surface, resulting in tight adhesion. Next, neutrophils migrate through the endothelium and enter the interstitial tissue. Within the tissue, neutrophils continue to migrate along a gradient formed by locally produced chemotactic factors. Finally, in order to reach the airway lumen, neutrophils also migrate through the lung epithelium.

During migration and upon arrival in the lung, neutrophils may contribute to tissue injury. Tissue injury prevails when neutrophils accumulate in unusually high numbers, when they receive inappropriate stimuli and/or when the activity of their products is not adequately controlled. Neutrophils are equipped with an array of preformed compounds that are stored in the various types of neutrophil granule, and that may be released upon stimulation. These compounds include serine and metalloproteinases, and nonenzymatic polypeptides such as neutrophil defensins. In addition, neutrophil stimulation also results in the synthesis and release of a number of mediators including reactive oxygen intermediates, lipid mediators and cytokines that may contribute to lung injury.

\section{Characteristics of neutrophil elastase, cathepsin G, proteinase 3 and neutrophil defensins}

\section{Neutrophil serine proteinases: elastase, cathepsin $G$ and proteinase 3}

Neutrophil elastase, cathepsin $\mathrm{G}$ and proteinase 3 are serine proteinases that are produced during neutrophil development in the bone marrow and stored in the azurophilic granules of mature neutrophils (fig. 1). The neutrophil elastase gene was originally reported to be localized on chromosome 11 (11q14) [35], but more recently the genes encoding neutrophil elastase and proteinase 3 were found to be clustered together with that encoding the structurally related azurocidin gene on chromosome 19 (19p13.3) [36]. As with the serine proteinases, azurocidin is also produced during neutrophil development, but unlike neutrophil elastase and proteinase 3 it lacks enzymatic activity [37]. The gene encoding cathepsin $\mathrm{G}$ is part of a gene cluster on chromosome 14q11.2 that also includes lymphocyte granzymes $\mathrm{B}$ and $\mathrm{H}$ and mast cell chymase. The proteins are produced as preproenzymes and processed to the mature protein during neutrophil maturation. The propiece may serve to protect the developing neutrophil from the potential detrimental effects of the mature serine proteinase.

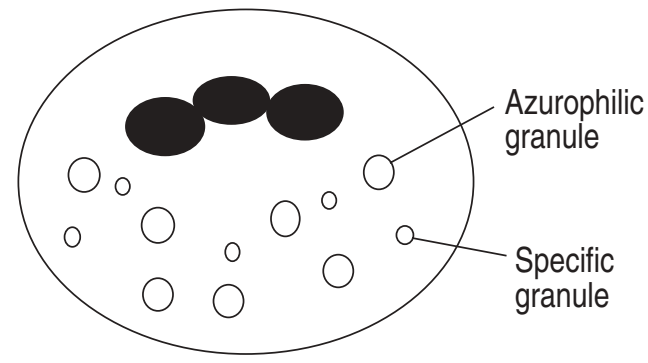

Fig. 1. - Serine proteinases and defensins in neutrophil azurophilic granules. Protein content (ng.10-6 cells): elastase, 1500; cathepsin G, 2500; proteinase 3, 1000; defensins, 6000 (data based on [34]).
Although the content of the azurophilic granules appears to be mainly destined for transfer to the phagolysosome, it may also be released by the neutrophil upon stimulation. High concentrations of neutrophil serine proteinases are found in purulent secretions of patients with chronic airway inflammation [38] and in the plasma of patients with disease such as sepsis and ARDS [39]. Once released into the extracellular environment, neutrophil serine proteinases may markedly affect the extracellular matrix and cells. Neutrophil serine proteinases have a broad substrate specificity and degrade a variety of extracellular matrix proteins including elastin, collagen (type I-IV), fibronectin, laminin and proteoglycans $[40,41]$. In addition to degrading the extracellular matrix, neutrophil elastase may also impair host defence against infection by reducing mucociliary clearance through a decrease in ciliary beat frequency of epithelial cells [42] and an increase in the production of mucus [43]. Furthermore, elastase-mediated cleavage of immunoglobulins, complement component $\mathrm{C} 3$ bi and the complement receptor for $\mathrm{C} 3 \mathrm{~b}(\mathrm{CRI})$ on neutrophils results in decreased phagocytosis of pathogens [44]. Finally, both elastase and cathepsin $\mathrm{G}$ impair T-cell function through cleavage of CD2, CD4 and CD8 on the surface of T-cells [45]. Neutrophil elastase not only degrades leukocyte surface molecules, but also induces eosinophil degranulation [46], suggesting that eosinophilic and neutrophilic inflammation interact.

The properties of neutrophil serine proteinases have been extensively studied in vitro, but these results are also supported by in vivo studies in experimental animals. Intratracheal instillation of elastase [24] and proteinase 3 [25], but not cathepsin G [47], results in the development of emphysematous lesions in experimental animals. In addition to these effects, neutrophil elastase causes secretory cell metaplasia and secretory granule discharge in the airway epithelium upon intratracheal administration [48, 49].

The enzymatic activity of released elastase, cathepsin G and proteinase 3 in the lung is tightly regulated by an antiproteinase screen that is composed of $\alpha_{1}$-PI, ALP, elafin and $\alpha_{2}$-macroglobulin. A disturbance in this balance between serine proteinases and their inhibitors is thought to play a key role in neutrophil-dominated lung inflammation. Such a disturbance may be the result of an excessive degree of neutrophil degranulation, or a genetic or functional deficiency of the serine proteinase inhibitors (fig. 2 ). This functional impairment of the activity of the proteinase inhibitors can be caused by exogenous compounds such as cigarette smoke, or endogenously produced factors such as the neutrophil-derived reactive oxygen intermediates [50], and matrix metalloproteinases [51]. The potential relevance of this mechanism to the pathogenesis of COPD is illustrated by the increased capacity of alveolar inflammatory cells from patients with pulmonary emphysema oxidatively to inactivate $\alpha_{1}$-PI in vitro [52], and by the increased levels of matrix metalloproteinases in BAL from these patients [53]. Neutrophil defensins also affect the balance between neutrophil serine proteinases and their inhibitors, since they bind to members of the serpin family of proteinase inhibitors that includes $\alpha_{1}$-PI [54]. As will be discussed elsewhere in this review, this interaction results not only in the impairment of some activities of defensins, but also reduces the antiproteinase activity of the serpin. 


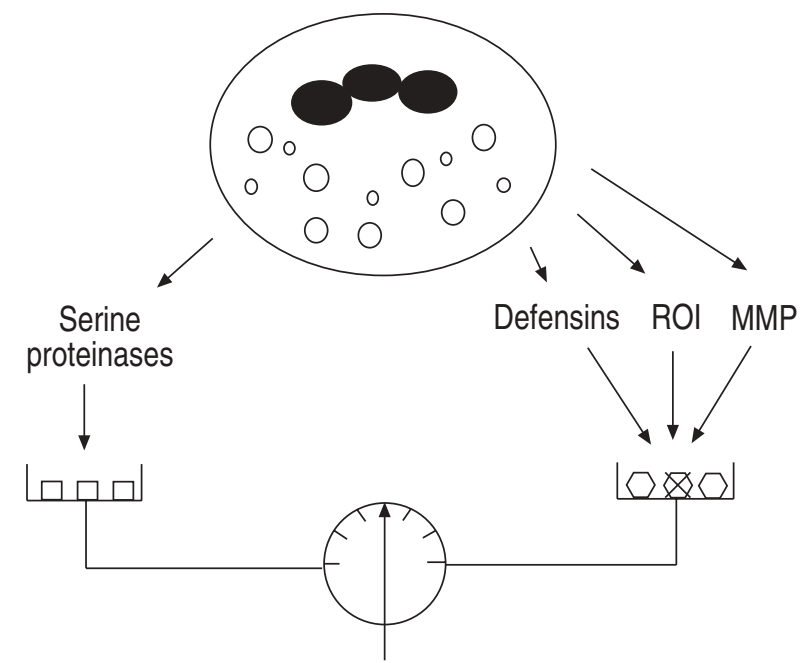

Fig. 2. - Serine proteinase-serine proteinase inhibitor balance: disturbance of the equilibrium by stimulated neutrophils. Neutrophil matrix metalloproteinases (MMP) are released in a latent form. Note that neutrophil defensins inhibit the antiproteinase activity of serpins, but not that of antileukoprotease. ROI: reactive oxygen intermediates. $\square:$ serine proteinase; $\square$ : serine proteinase inhibitor; $\$$ : inactivated serine proteinase inhibitor.

\section{Defensins}

The human defensin family now comprises eight members, four of which are known to be expressed in neutrophils (table 1), (for recent reviews, [55-57]). Human neutrophil defensins (human neutrophil peptides (HNP)-1, $-2,-3$ and 4 ) are small (relative molecular mass 3,540 ) cationic peptides that were first identified on the basis of their antimicrobial activity. They lack enzymatic activity, and like the serine proteinases, are produced during neutrophil development as preprodefensins [58, 59]. The neutrophil defensin gene for HNP-1 has been mapped to chromosome 8p23 [60]. Mature defensins are stored in a dense subset of azurophilic granules that contains no or little elastase and myeloperoxidase [61], and constitute $30-50 \%$ of the total protein content of the azurophilic granules (fig. 1).

Structurally, neutrophil defensins are part of the classical or $\alpha$-defensin subfamily that also includes human defensin (HD)-5 and -6. HD-5 and -6 are present in Paneth cells in the intestine, and serve to protect the small intestine from infectious micro-organisms. Recently, the first members of the human $\beta$-defensin family were identified as human $\beta$-defensin (hBD)-1 and -2. hBD-1 was first isolated from human blood filtrates [62] and later shown to be produced mainly by epithelia from the urogenital tract [63]. In vitro studies demonstrated that it is a major con-

Table 1. - Human $\alpha$ - and $\beta$-defensins

\begin{tabular}{lcl}
\hline Defensin subfamily & Members & Expression \\
\hline$\alpha$-defensins & HNP1-4 & Neutrophils \\
$\beta$-defensins & HD-5, -6 & Paneth cells \\
& hBD-1 & $\begin{array}{c}\text { Epithelial cells } \\
\text { (constitutive expression) }\end{array}$ \\
& hBD-2 & $\begin{array}{c}\text { Epithelial cells } \\
\text { (inducible expression) }\end{array}$ \\
\hline
\end{tabular}

$\overline{\text { HNP: human neutrophil peptide; HD: human defensin; hBD: }}$ human $\beta$-defensin. tributor to the antimicrobial activity of bronchial epithelial cells [64]. Another member of the hBD family was recently isolated from psoriatic scale extracts and named hBD-2 [65]. Marked expression was found in the skin, lungs and trachea, indicating that its expression pattern is different from that of hBD-1. Furthermore, the expression of hBD-1 does not appear to be upregulated by inflammatory stimuli [63], whereas that of hBD-2 is increased by the stimulation of keratinocytes with TNF- $\alpha$, bacteria and fungi [65].

Neutrophil defensins were originally identified as antimicrobial peptides that display activity against Gram-negative and Gram-positive bacteria, fungi and enveloped viruses. Their primary function appears to reside in killing ingested micro-organisms after transfer from the defensin storage site to the phagolysosome. However, along with the serine proteinases, defensins may also be released upon neutrophil stimulation [66]. Indeed, defensins are present in high concentrations together with the neutrophil serine proteinases in purulent secretions from patients with chronic airway inflammation $[54,67]$ and in the plasma of patients with sepsis or meningitis [68]. Furthermore, defensins are a major constituent of human wound and blister fluid [69]. In addition to their antimicrobial activity, neutrophil defensins display extraphagosomal activities that may be relevant to both inflammation and the immune response. They display marked cytotoxic activity against eukaryotic cells at high concentrations $[55,57]$. This activity is controlled by a variety of plasma proteins that include albumin, $\alpha_{2}$-macroglobulin [70] and serine proteinase inhibitors (serpins) such as $\alpha_{1}$-PI and $\alpha_{1}$-ACT, but it is not affected by the nonserpin inhibitor of elastase, antileukoprotease (ALP) [54]. Complex formation of defensins with serpins results not only in inhibition of, for instance, the cytotoxic activity of defensins, but also in an inhibition of the antiproteinase activity of the serpin [54]. Thus, defensins may also affect the balance between serine proteinase and serpins (fig. 2), and their extracellular activity may be less restricted in patients with $\alpha_{1}$-PI and $\alpha_{1}$-ACT deficiency. In addition to their antimicrobial and cytotoxic activities, defensins induce mast cell degranulation [71], modulate TNF- $\alpha$ production by stimulated monocytes [72] and act as corticostatins by inhibiting the adrenocorticotropic hormone-induced production of cortisol by adrenal cells [73]. Defensins also equip the neutrophil with the capacity to attract other inflammatory cells directly upon arrival in tissue, since neutrophil defensins are chemotactic for monocytes [74] and T-lymphocytes [75]. Azurocidin, which is also stored in the azurophilic granules, displays a similar spectrum of chemotactic activity [75]. Finally, defensins may be involved in wound repair because, at subcytotoxic concentrations, they act as growth factors for epithelial cells and for fibroblasts [76].

\section{Cytotoxic and stimulatory activities of neutrophil serine proteinases and defensins towards lung epithelial cells}

Stimulation and subsequent degranulation of neutrophils results in the release of neutrophil elastase, cathepsin G, proteinase 3 and defensins. These granule proteins may be present in very high concentrations, especially in the sequestered environment between an adherent neutrophil and its target. Because inhibitors such as $\alpha_{1}$-PI have limited 
access to the pericellular space between a neutrophil adherent to its target [77] and/or because they are overwhelmed by the high concentration of the granule proteins [78], these granule proteins may cause injury to cells such as those in the endothelium and the epithelium, and to extracellular matrix components.

Based on the high concentrations of neutrophil granule proteins present in purulent secretions, increased neutrophil numbers in the airway lumen of COPD patients [4-7] and the presence of neutrophils in the epithelium of patients with COPD [11], the epithelium is likely to be exposed frequently to products of degranulated neutrophils. Both injurious and stimulatory effects of neutrophil serine proteinases and defensins on the epithelium have been described and are summarized in table 2.

\section{Cytotoxicity}

Isolated neutrophil serine proteinases and defensins cause detachment and cytolysis of endothelial and epithelial cells in vitro [42, 54, 79-82, 90]. Both elastase and proteinase 3 cause endothelial cell apoptosis, which correlates with detachment of the cell from the matrix [91]. At present it is not clear whether apoptosis results in cell detachment or whether detachment promotes apoptosis. It is also unknown whether elastase and proteinase 3 have similar effects on lung epithelial cells. Because stimulated neutrophils release their serine proteinases and defensins simultaneously, the interaction between defensins and the serine proteinases elastase and cathepsin $\mathrm{G}$ was analysed recently with respect to their effects on cells of the alveolar epithelial cell line A549 [80]. Both elastase and cathepsin $\mathrm{G}$ caused detachment, reaching maximum values after $6 \mathrm{~h}$ of incubation without obvious cytotoxicity, as judged by a ${ }^{51} \mathrm{Cr}$-release assay. A marked additive effect of elastase and cathepsin G on detachment of A549 epithelial cells was observed [80], which is in line with previous observations on the effects of combinations of these serine proteinases on the stimulation of airway gland cell degranulation [43] and elastin degradation [92]. In contrast to

Table 2. - Effects of neutrophil serine proteinases and defensins on epithelium: results from in vivo and in vitro studies

\begin{tabular}{lcc}
\hline Effect & $\begin{array}{c}\text { Involved granule } \\
\text { protein }\end{array}$ & [Ref.] \\
\hline Cell lysis & HNP & {$[54,79,80]$} \\
Cell detachment & NE, CathG & {$[79-81]$} \\
$\begin{array}{l}\text { Induced epithelial permeability } \\
\text { Reduction of ciliary beat } \\
\text { frequency }\end{array}$ & $\mathrm{NE}$, CathG, HNP & {$[82,83]$} \\
$\begin{array}{l}\text { Induction of secretory cell } \\
\text { metaplasia }\end{array}$ & $\mathrm{NE}$ & {$[42]$} \\
$\begin{array}{l}\text { Mucus secretion from airway } \\
\text { gland cells }\end{array}$ & $\mathrm{NE}, \mathrm{CathG}$ & {$[47]$} \\
$\begin{array}{l}\text { Increased IL-8 and PGE } \\
\text { Modulation of ALP production* }\end{array}$ & $\mathrm{NE}, \mathrm{CathG}$ & {$[43]$} \\
$\begin{array}{l}\text { Increased cell proliferation } \\
\text { NE }+ \text { GathG }\end{array}$ & {$[84-87]$} \\
\hline
\end{tabular}

IL-8: interleukin-8; $\mathrm{PGE}_{2}$ : prostaglandin $\mathrm{E}_{2}$; ALP: antileukoprotease; HNP: human neutrophil peptide (neutrophil defensins); NE: neutrophil elastase; CathG: cathepsin G. *: whereas NE and CathG apparently increase ALP messenger ribonucleic acid levels in epithelial cells, they decrease ALP protein secretion [89]. the serine proteinases, neutrophil defensins caused A549 cell lysis upon prolonged $(20 \mathrm{~h})$ incubation. When incubated together with the serine proteinases, defensins markedly reduced elastase- or cathepsin G-induced detachment; conversely, the serine proteinases also inhibited defensininduced cell lysis (fig. 3). Whereas the activities of cathepsin $\mathrm{G}$ and defensins towards A549 cells were restricted by inhibitory interactions between these granule proteins, an additive effect of cathepsin $G$ and defensins with respect to their antimicrobial activity was noted. These results indicate that the potential detrimental effects of released granule proteins are limited by an interaction between simultaneously released defensins and serine proteinases, but this mutual inhibition does not apply to the antimicrobial activity of these proteins. The inhibitory interaction between defensins and the serine proteinases could not be explained by either an effect of defensins on the proteolytic activity of the serine proteinases or degradation of defensins by elastase or cathepsin G. It is also unlikely that the inhibitory interactions are explained by competition for binding sites at the epithelial cell surface. As discussed elsewhere in this review, both defensins and elastase stimulate chemokine synthesis in epithelial cells, and elastase
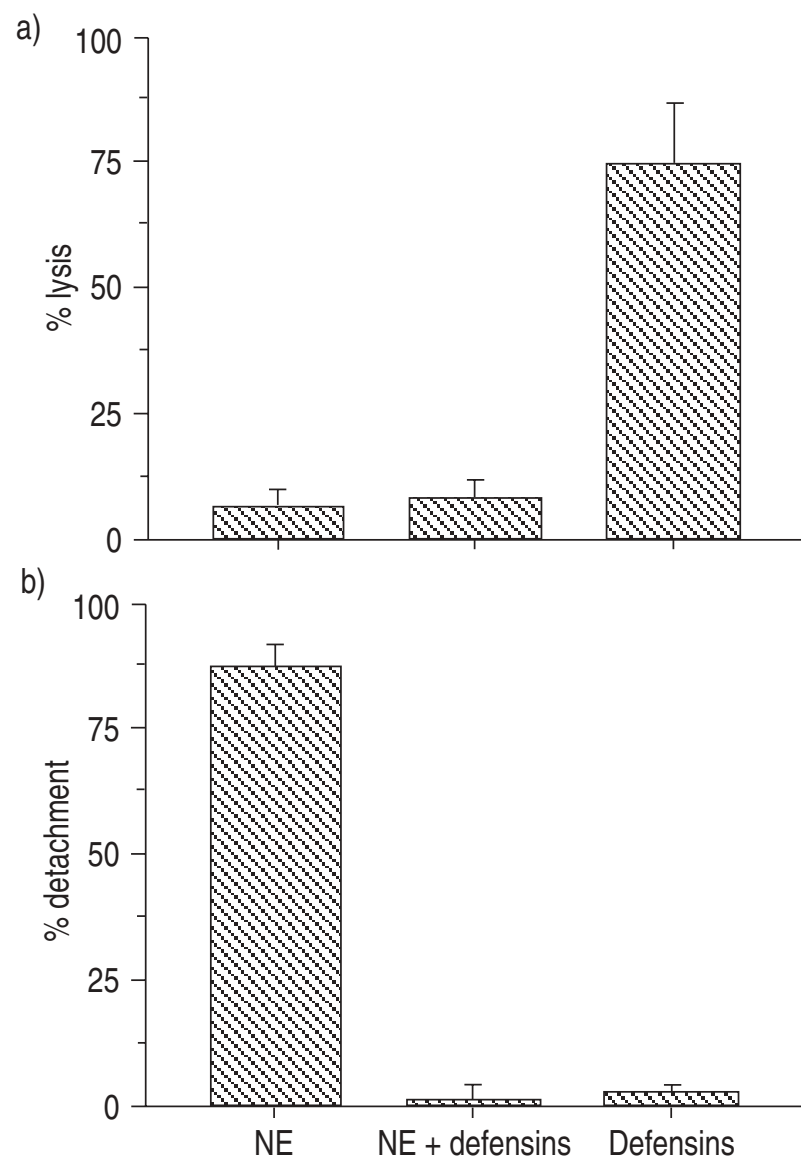

Fig. 3. - Inhibitory interactions between neutrophil defensins and the serine proteinases elastase and cathepsin G. ${ }^{51} \mathrm{Cr}$-labelled A549 epithelial cells were incubated with various combinations of defensins (100 $\left.\mu \mathrm{g} \cdot \mathrm{mL}^{-1}\right)$ and elastase $\left(\mathrm{NE} ; 10 \mu \mathrm{g} \cdot \mathrm{mL}^{-1}\right)$, alone or in combination. a) Cell lysis was determined following $20 \mathrm{~h}$ of incubation, and b) cell detachment was quantified after $6 \mathrm{~h}$. See [80] for experimental details. Results are expressed as mean \pm SEM of five separate experiments. Similar results to those obtained with elastase were also found for cathepsin G. 
and cathepsin $\mathrm{G}$ induce gland cell degranulation. Since these processes involve the activation of intracellular signal transduction pathways, it may be speculated that the inhibitory interaction between neutrophil serine proteinase and defensins is the result of intracellular cross-talk between signal transduction pathways. These processes are currently being studied in more detail. Taken together, the data suggest that the cytotoxic activity of released serine proteinases and defensins is restricted not only by proteinase inhibitors, but also by an inhibitory interaction between the released proteins. Despite these inhibitory interactions between released granule proteins, stimulated neutrophils cause epithelial cell injury in vitro. This may be explained by the contribution of other neutrophil mediators such as reactive oxygen intermediates and metalloproteinases to epithelial cell injury, or it may be the result of differential release of azurophilic granule proteins.

\section{Stimulation of epithelial cells}

At sites of inflammation, neutrophils not only cause tissue injury directly, but may also stimulate the recruitment of additional inflammatory cells by contributing to the generation of local inflammatory signals (fig. 4). This is partly mediated by the capacity of neutrophils to produce neutrophil chemoattractants such as leukotriene B4 and IL-8 [93]. In addition, activated neutrophils may produce cytokines such as IL-1 and TNF [93, 94] that may stimulate other cells, including epithelial cells, to produce chemoattractants. Evidence is now accumulating that neutrophil degranulation may also result in the generation of chemotactic signals. As discussed elsewhere in this review, neutrophil defensins and azurocidin have chemotactic activity towards monocytes and T-lymphocytes $[74,75]$. In

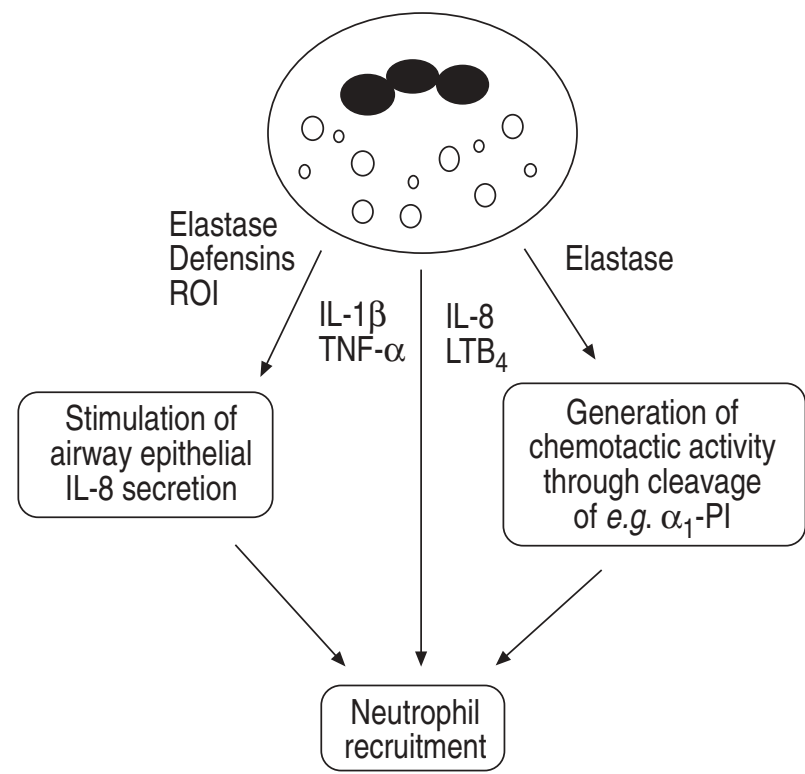

Fig. 4. - Role of intraluminal neutrophil stimulation in recruitment of neutrophils into the lung. Upon stimulation, neutrophils may release stored elastase and defensins, and synthesize reactive oxygen intermediates (ROI), leukotriene $\mathrm{B}_{4}\left(\mathrm{LTB}_{4}\right)$ and cytokines such as interleukin (IL)$1 \beta$, tumour necrosis factor (TNF)- $\alpha$ and IL- 8 . These compounds may directly or indirectly stimulate neutrophil recruitment. Note that both neutrophil-derived defensins and azurocidin display marked chemotactic activity towards monocytes and T-lymphocytes. addition, elastase- $\alpha_{1}$-PI complexes have neutrophil chemoattractant activity [95], and elastase generates neutrophil chemotactic activity through the cleavage of fibrin [96]. Neutrophil degranulation may also indirectly result in the recruitment of inflammatory cells by stimulating resident lung cells to generate chemotactic signals. Neutrophil elastase stimulates the production of IL-8 in bronchial [84] and nasal [85] epithelial cells, as well as in endothelial cells [97]. This stimulation is inhibited by $\alpha_{1}$-PI and ALP, suggesting the involvement of the enzymatic activity of neutrophil elastase $[84,97]$. A role for elastase in neutrophil recruitment through the stimulation of IL-8 release in vivo is supported by the observation that the treatment of cystic fibrosis patients with ALP results in decreases in active elastase, IL- 8 and neutrophil numbers in the epithelial lining fluid [98]. Although ALP has been available for patient studies, these important observations have not yet been confirmed in other studies.

In vitro proteinase 3 also stimulates the production of IL-8 in endothelial cells [97], and neutrophil defensins increase the production of IL-8 [86] and ENA-78 [99] by lung epithelial cells. Defensin-induced release of IL-8 is fully inhibited by the serine proteinase inhibitor $\alpha_{1}-\mathrm{PI}$, which is in line with the observation that $\alpha_{1}$-PI also inhibits defensin-induced cytotoxicity [54]. In addition, it is inhibited by elastase and cathepsin $\mathrm{G}$, as has also been observed for defensin-induced cytotoxicity [80]. The defensininduced enhancement of IL-8 expression is probably due to increased transcription, since the effect of defensins is inhibited by actinomycin $\mathrm{D}$, and defensins increase the levels of IL-8 messenger ribonucleic acid (mRNA) without affecting its stability [86]. Likewise, elastase- and proteinase 3-induced IL-8 secretion is also the result of de novo IL-8 protein synthesis [ 84,97$]$. It has been suggested that elastase may also be involved in the resolution phase of neutrophil-dominated inflammation, because elastase induces an increase in the levels of ALP mRNA in airway epithelial cells in vitro [88]. However, whereas both elastase and cathepsin G increase ALP mRNA levels, they decrease ALP protein release from cells of airway epithelial cell lines [89]. Finally, human neutrophil elastase also stimulates the production of prostaglandin $E_{2}$ in guineapig tracheal epithelial cells [87].

What signal transduction routes are employed by serine proteinases and defensins to stimulate epithelial cells? Cellular deformation and associated disruption of microtubules were found to be involved in elastase-induced IL-8 production in epithelial cells [100]. The production of both elastase-induced epithelial IL-8 and ALP mRNA production is mediated in part by the activation of protein kinase $C$ and tyrosine kinase activities $[100,101]$. In contrast, protein kinase $\mathrm{C}$ does not appear to be involved in elastase- or cathepsin G-induced degranulation of airway gland cells [102]. No studies have yet been performed to investigate the mechanisms involved in defensin-induced stimulation of epithelial chemokine secretion. A first step in a signal transduction cascade resulting in IL-8 production may be the formation of voltage-dependent ion channels in the membrane of target cells [57, 103]. Experiments employing specific inhibitors of selected signal transduction pathways are required to elucidate further the mechanisms leading to defensin-stimulated chemokine production in epithelial cells. 


\section{Concluding remarks}

Neutrophils contain large amounts of granule proteins that are released during inflammatory processes in the lung, and have potent injurious and stimulatory activities towards cells of the lung epithelium. These granule proteins include the neutrophil serine proteinases elastase, cathep$\sin \mathrm{G}$ and proteinase 3, and nonenzymatic neutrophil defensins. Among these proteins, elastase has been studied most extensively in vivo, whereas very few data are available on the effects of defensins in vivo. Based on their in vitro activities, defensins may be involved in inflammatory processes and the subsequent repair reaction. Studies aimed at providing insight into the role of defensins in inflammation in vivo are hampered by the fact that no compounds are available that selectively inhibit defensin activity. The availability of small, synthetic elastase inhibitors for in vivo studies that, unlike $\alpha_{1}$-proteinase inhibitor, do not affect defensin activity, may contribute further to our knowledge on the pro-inflammatory and anti-inflammatory activities of serine proteinases and defensins in neutrophil-dominated inflammation.

\section{References}

1. Fletcher C, Peto R. The natural history of chronic airflow obstruction. Br Med J 1977; 1: 1645-1648.

2. Snider GL. Chronic obstructive pulmonary disease: risk factors, pathophysiology and pathogenesis. Annu Rev Med 1989; 40: 411-429.

3. Hunninghake GW, Crystal RG. Cigarette smoking and lung destruction. Accumulation of neutrophils in the lungs of cigarette smokers. Am Rev Respir Dis 1983; 128: 833-838.

4. Thompson AB, Daughton D, Robbins RA, Ghafouri MA, Oehlerking M, Rennard S. Intraluminal airway inflammation in chronic bronchitis. Characterization and clinical parameters. Am Rev Respir Dis 1989; 140: 1527-1537.

5. Linden M, Rasmussen JB, Piitulanen E, et al. Airway inflammation in smokers with nonobstructive and obstructive chronic bronchitis. Am Rev Respir Dis 1993; 148: 1226-1232.

6. Lacoste JY, Bousquet J, Chanez P, et al. Eosinophilic and neutrophilic inflammation in asthma, chronic bronchitis and chronic obstructive pulmonary disease. J Allergy Clin Immunol 1993; 92: 537-548.

7. Keatings VM, Collins PD, Scott DM, Barnes PJ. Difference in interleukin- 8 and tumor necrosis factor- $\alpha$ in induced sputum from patients with chronic obstructive pulmonary disease or asthma. Am J Respir Crit Care Med 1996; 153: 530-534.

8. Di Stefano A, Turato G, Maestrelli P, et al. Airflow limitation in chronic bronchitis is associated with T-lymphocytes and macrophage infiltration of the bronchial mucosa. Am J Respir Crit Care Med 1996; 153: 629-632.

9. O'Shaughnessy TC, Ansari TW, Barnes NC, Jeffery PK. Inflammation in bronchial biopsies of subjects with chronic bronchitis: inverse relationship of CD8+ T lymphocytes with FEV1. Am J Respir Crit Care Med 1997; 155: 852-857.

10. Finkelstein R, Fraser RS, Ghezzo H, Cosio MG. Alveolar inflammation and its relation to emphysema in smokers. Am J Respir Crit Care Med 1995; 152: 1666-1672.

11. O'Shaughnessy TC, Ansari TW, Barnes NC, Jeffery PK. Inflammatory cells in the airway surface epithelium of bronchitic smokers with and without airflow obstruction. Eur Respir J 1996; 9: Suppl. 23, 14s (Abstract).
12. McCrea KA, Ensor JE, Nall K, Bleecker ER, Hasday JD. Altered cytokine regulation in the lungs of cigarette smokers. Am J Respir Crit Care Med 1994; 150: 696-703.

13. Mio T, Romberger DJ, Thompson AB, Robbins RA, Heires A, Rennard SI. Cigarette smoke induces interleukin-8 release from human bronchial epithelial cells. Am J Respir Crit Care Med 1997; 155: 1770-1776.

14. Damiano W, Tsang A, Kucich U, et al. Immunolocalization of elastase in human emphysematous lungs. J Clin Invest 1986; 78: 482-493.

15. Kucich U, Christner P, Lippmann M, et al. Immunologic measurement of elastin-derived peptides in human serum. Am Rev Respir Dis 1983; 127: S28-S30.

16. Schriver EE, Davidson JM, Sutcliffe MC, Swindell BB, Bernard GR. Comparison of elastin peptide concentrations in body fluids from healthy volunteers, smokers, and patients with chronic obstructive pulmonary disease. Am Rev Respir Dis 1992; 145: 762-766.

17. Gottlieb DJ, Stone PJ, Sparrow D, et al. Urinary desmosine excretion in smokers with and without rapid decline of lung function. The normative aging study. Am J Respir Crit Care Med 1997; 154: 1290-1295.

18. Bos R, Van Leuven CJM, Stolk J, Hiemstra PS, Ronday HK, Nieuwenhuizen W. An enzyme immunoassay for polymorphonuclear leucocyte-mediated fibrinogenolysis. Eur J Clin Invest 1997; 27: 148-156.

19. Laurell CB, Eriksson S. The electrophoretic $\alpha 1$-globulin pattern of serum in $\alpha 1$-antitrypsin deficiency. Scand $J$ Clin Lab Invest 1996; 15: 132-140.

20. Brantly ML, Paul LD, Miller BH, Falk RT, Wu M, Crystal RG. Clinical features and history of the destructive lung disease associated with alpha-1-antitrypsin deficiency of adults with pulmonary symptoms. Am Rev Respir Dis 1988; 138: 327-336.

21. Sandford AJ, Weir TD, Pare PD. Genetic risk factors for chronic obstructive pulmonary disease. Eur Respir J 1997; 10: 1380-1391.

22. Kalsheker NA, Morgan K. Regulation of the alpha 1-antitrypsin gene and a disease-associated mutation in a related enhancer sequence. Am J Respir Crit Care Med 1994; 150: S183-S189.

23. Feldmann D, Plouvier E, Jacquemin A, Laroze F, Just J, Grimfield A. Molecular analysis of the secretory leukocyte protease inhibitor gene in COPD. Eur Respir J 1996; 9: Suppl. 23, 16s-17s (Abstract).

24. Janoff A, Sloan B, Weinbaum G, et al. Experimental emphysema induced with purified human neutrophil elastase: tissue localization of the instilled protease. Am Rev Respir Dis 1977; 115: 461-478.

25. Kao RC, Wehner NG, Skubitz KM, Gray BH, Hoidal JR. Proteinase 3: a distinct human polymorphonuclear leukocyte proteinase that produces emphysema in hamsters. $J$ Clin Invest 1988; 82: 1963-1973.

26. Stolk J, Rudolphus A, Davies P, et al. Induction of emphysema and bronchial mucus cell hyperplasia by intratracheal instillation of lipopolysaccharide in the hamster. J Pathol 1992; 167: 349-356.

27. Cavarra E. Martorana PA, Gambelli F, de Santi M, van Even P, Lungarella G. Neutrophil recruitment into the lungs is associated with increased lung elastase burden, decreased lung elastin, and emphysema in $\alpha 1$ proteinase inhibitor-deficient mice. Lab Invest 1996; 75: 273-280.

28. Rudolphus A, Stolk J, Dijkman JH, Kramps JA. Inhibition of lipopolysaccharide-induced pulmonary emphysema by intratracheally instilled recombinant secretory proteinase inhibitor. Am Rev Respir Dis 1993; 147: 442-447.

29. Hogg JC. Neutrophil traffic. In: Crystal RG, West JB, Barnes PJ, Weibel ER, eds. The Lung: Scientific Foundations. 2nd ed. Philadelphia, PA, Lippincott-Raven, 1997; pp. 891-904. 
30. Brown EJ. Adhesive interactions in the immune system. Trends Cell Biol 1997; 7: 289-295.

31. Richman-Eisenstat JBY, Jorens PG, Hebert CA, Ueki I, Nadel JA. Interleukin-8: an important chemoattractant in sputum of patients with chronic inflammatory airway diseases. Am J Physiol (Lung Cell Mol Physiol) 1993; 264: L413-L418.

32. Baggiolini M, Dewald B, Moser B. Interleukin-8 and related chemotactic cytokines - CXC and CC chemokines. Adv Immunol 1994; 55: 97-179.

33. Wuyts A, Van Osselaer N, Haelens A, et al. Characterization of synthetic human granulocyte chemotactic protein 2: usage of chemokine receptors CXCR1 and CXCR2 and in vivo inflammatory properties. Biochemistry 1997; 36: 2716-2723.

34. Gabay JE, Almeida RP. Antibiotic peptides and serine protease homologs in human polymorphonuclear leukocytes: defensins and azurocidin. Curr Opin Immunol 1993; 5: 97-102.

35. Takahashi H, Nukiwa T, Yoshimura K, et al. Structure of the human neutrophil elastase gene. J Biol Chem 1988; 263: 14739-14747.

36. Jenne DE. Structure of the azurocidin, proteinase 3, and neutrophil elastase genes. Implications for inflammation and vasculitis. Am J Respir Crit Care Med 1994; 150: S147-S154.

37. Wilde CG, Snable JL, Griffith JE, Scott RW. Characterization of two azurophilic granule proteases with activesite homology to neutrophil elastase. J Biol Chem 1990; 265: 2038-2041.

38. Stockley RA. The role of proteinases in the pathogenesis of chronic bronchitis. Am J Respir Crit Care Med 1994; 150: S109-S113.

39. Donnelly SC, MacGregor I, Zamani A, et al. Plasma elastase levels and the development of the adult respiratory distress syndrome. Am J Respir Crit Care Med 1995; 151: 1428-1433.

40. Bieth JG. Elastases: catalytic and biological properties. In: Mecham RP, ed. Regulation of Matrix Accumulation. Orlando, FL, Academic Press, 1986; pp. 218-320.

41. McElvaney NG, Crystal RG. Proteases and lung injury. In: Crystal RG, West JB, Barnes PJ, Weibel ER, eds. The Lung: Scientific Foundations. 2nd ed. Philadelphia, PA, Lippencott-Raven, 1997, pp. 2205-2218.

42. Amitani R, Wilson R, Rutman A, et al. Effects of human neutrophil elastase and Pseudomonas aeruginosa proteinases on human respiratory epithelium. Am J Respir Cell Mol Biol 1991; 4: 26-32.

43. Sommerhoff CP, Nadel JA, Basbaum CB, Caughey GH. Neutrophil elastase and cathepsin $\mathrm{G}$ stimulate secretion from cultured bovine airway gland serous cells. J Clin Invest 1990; 85: 682-689.

44. Tosi MF, Zakem H. Berger M. Neutrophil elastase cleaves C3bi on opsonized Pseudomonas as well as CRI on neutrophils to create a functionally important opsonin receptor mismatch. J Clin Invest 1990; 86: 300-308.

45. Doring G, Frank F, Boudier C, Herbert S, Fleischer B, Bellon G. Cleavage of lymphocyte surface antigens CD2, $\mathrm{CD} 4$, and $\mathrm{CD} 8$ by polymorphonuclear leukocyte elastase and cathepsin $\mathrm{G}$ in patients with cystic fibrosis. $J$ Immunol 1995; 154: 4842-4850.

46. Liu H, Lazarus SC, Caughey GH, Fahy JV. Neutrophil elastase degranulates eosinophils in vitro. Am Rev Respir Dis 1997; 155: A67 (Abstract).

47. Lucey EC, Stone PJ, Breuer R, et al. Effect of combined human neutrophil cathepsin $\mathrm{G}$ and elastase on induction of secretory cell metaplasia and emphysema in hamsters, with in vitro observations on elastolysis by these enzymes. $\mathrm{Am}$ Rev Respir Dis 1985; 132: 362-366.
48. Lucey EC, Stone PJ, Snider GL. Consequences of proteolytic injury. In: Crystal RG, West JB, Barnes PJ, Weibel ER, eds. The Lung: Scientific Foundations. 2nd ed. Philadelphia, PA, Lippencott-Raven Publishers, 1997; pp. 22372250.

49. Rudolphus A, Kramps JA, Dijkman JH. Effect of human antileucoprotease on experimental emphysema. Eur Respir J 1991; 4: 31-39.

50. Johnson D, Travis J. The oxidative inactivation of human $\alpha 1$ proteinase inhibitor: further evidence for the methionine at the reactive centre. J Biol Chem 1979; 254: 4022-4026.

51. Vissers MCM, George PM, Bathurst IC, Brennan SO, Winterbourn CC. Cleavage and inactivation of alpha-1antitrypsin by metalloproteinases released from neutrophils. J Clin Invest 1988; 82: 706-711.

52. Wallaert B, Gressier B, Marquette C, et al. Inactivation of $\alpha 1$-proteinase inhibitor by alveolar inflammatory cells from smoking patients with or without emphysema. Am Rev Respir Dis 1993; 147: 1537-1543.

53. Finlay GA, Russell KJ, McMahon KJ, et al. Elevated levels of matrix metalloproteinases in bronchoalveolar lavage fluid of emphysematous patients. Thorax 1997; 52: 502-506.

54. Panyutich AV, Hiemstra PS, Van Wetering S, Ganz T. Human neutrophil defensin and serpins form complexes and inactivate each other. Am J Respir Cell Mol Biol 1995; 12: 351-357.

55. Lehrer RI, Lichtenstein AK, Ganz T. Defensins: antimicrobial and cytotoxic peptides of mammalian cells. Annu Rev Immunol 1993; 11: 105-128.

56. Martin E, Ganz T, Lehrer RI. Defensins and other endogenous peptide antibiotics of vertebrates. J Leukoc Biol 1995; 58: 128-136.

57. Kagan BL, Ganz T, Lehrer RI. Defensins: a family of antimicrobial and cytotoxic peptides. Toxicology 1994; 87: 131-149.

58. Harwig SSL, Park ASK, Lehrer RI. Characterization of defensin precursors in mature human neutrophils. Blood 1992: 79: 1532-1537.

59. Valore EV, Ganz T. Posttranslational processing of defensins in immature human myeloid cells. Blood 1992; 79: $1538-1544$.

60. Sparkes RS, Kronenberg M, Heinzmann C, et al. Assignment of defensin gene(s) to human chromosome 8p23. Genomics 1989; 5: 240-244.

61. Rice WG, Ganz T, Kinkade JM, Selsted ME, Lehrer RI, Parmley RT. Defensin-rich dense granules of human neutrophils. Blood 1987; 70: 757-765.

62. Bensch KW, Raida M, Magert HJ, Schulz-Knappe P, Forssmann WG. hBD-1: a novel beta-defensin from human plasma. FEBS Lett 1995; 368: 331-335.

63. Zhao R, Wang I, Lehrer RI. Widespread expression of beta-defensin hBD-1 in human secretory glands and epithelial cells. FEBS Lett 1996; 396: 319-322.

64. Goldman MJ, Anderson GM, Stolzenberg ED, Kari UP, Zasloff M, Wilson JM. Human $\beta$-defensin- 1 is a salt-sensitive antibiotic in the lung that is inactivated in cystic fibrosis. Cell 1997; 88: 553-560.

65. Harder J, Bartels J, Christophers E, Schröder J. A peptide antibiotic from human skin. Nature 1997; 387: 861.

66. Ganz T. Extracellular release of antimicrobial defensins by human polymorphonuclear leukocytes. Infect Immun 1987; 55: 568-571.

67. Soong LB, Ganz T, Ellison A, Caughey GH. Purification and characterization of defensins from cystic fibrosis sputum. Inflamm Res 1997; 46: 98-102.

68. Panyutich AV, Panyutich EA, Krapivin VA, Baturevich EA, Ganz T. Plasma defensin concentrations are elevated in patients with septicemia or bacterial meningitis. $J \mathrm{Lab}$ Clin Med 1993; 122: 202-207. 
69. Frohm M, Gunne H, Bergman A-C, et al. Biochemical and antibacterial analysis of human wound and blister fluid. Eur J Biochem 1996; 237: 86-92.

70. Panyutich A, Ganz T. Activated alpha2-macroglobulin is a principal defensin-binding protein. Am J Respir Cell Mol Biol 1991; 5: 101-106.

71. Yamashita T, Saito K. Purification, primary structure, and biological activity of guinea pig neutrophil cationic peptides. Infect Immun 1989; 57: 2405-2409.

72. Misuno NI, Kolesnikova TS, Lehrer RI, Ganz T, Voitenok NN. Effect of defensin HNP-1 of human neutrophils on production of tumor necrosis factor $\alpha$ by human blood monocytes in vitro. Bull Exp Biol Med 1992; 113: 709712.

73. Zhu Q, Hu J, Mulay S, Esch F, Shimasaki S, Solomon S. Isolation and structure of corticostatin peptides from rabbit fetal and adult lung. Proc Natl Acad Sci USA 1988; 85: 592-596.

74. Territo MC, Ganz T, Selsted ME, Lehrer R. Monocyte-chemotactic activity of defensins from human neutrophils. J Clin Invest 1989; 84: 2017-2020.

75. Chertov O, Michiel DF, Xu L, et al. Identification of defensin-1, defensin-2 and CAP37/azurocidin as T-cell chemoattractant proteins released from interleukin-8stimulated neutrophils. J Biol Chem 1996; 271: 2935 2940.

76. Murphy CJ, Foster BA, Mannis MJ, Selsted ME, Reid TW. Defensins are mitogenic for epithelial cells and fibroblasts. J Cell Physiol 1993; 155: 408-413.

77. Campbell EJ, Campbell MA. Pericellular proteolysis by neutrophils in the presence of proteinase inhibitors: effects of substrate opsonization. J Cell Biol 1988; 106: 667-676.

78. Liou TG, Campbell EJ. Quantum proteolysis resulting from release of single granules by human neutrophils: a novel, nonoxidative mechanism of extracellular proteolytic activity. J Immunol 1996; 157: 2624-2631.

79. Okrent DG, Lichtenstein AK, Ganz T. Direct cytotoxicity of polymorphonuclear leukocyte granule proteins to human lung-derived cells and endothelial cells. Am Rev Respir Dis 1990; 141: 179-185.

80. Van Wetering S, Mannesse-Lazeroms SPG, Dijkman JH, Hiemstra PS. Effect of neutrophil serine proteinases and defensins on lung epithelial cells. Modulation of cytotoxicity and IL-8 production. J Leukoc Biol 1997; 62: 217226.

81. Kamp DW, Dunne M, Dykewicz MS, Sbalchiero JS, Weitzman SA, Dunn MM. Asbestos-induced injury to cultured human pulmonary epithelial-like cells: role of neutrophil elastase. J Leukoc Biol 1993; 54: 73-80.

82. Nygaard SD, Ganz T, Peterson MW. Defensins reduce the barrier integrity of a cultured epithelial monolayer without cytotoxicity. Am J Respir Cell Mol Biol 1993; 8: 193 200.

83. Peterson MW, Walter ME, Nygaard SD. Effect of neutrophil mediators on epithelial permeability. Am J Respir Cell Mol Biol 1995; 13: 719-727.

84. Nakamura H, Yoshimura K, McElvaney NG, Crystal RG. Neutrophil elastase in respiratory epithelial lining fluid of individuals with cystic fibrosis induces interleukin- 8 gene expression in a human bronchial epithelial cell line. $J$ Clin Invest 1992; 89: 1478-1484.

85. Bedard M, McClure CD, Schiller NL, Francoeur C, Cantin A, Denis M. Release of interleukin-8, interleukin-6, and colony-stimulating factors by upper airway epithelial cells: implications for cystic fibrosis. Am J Respir Cell Mol Biol 1993; 9: 455-462

86. Van Wetering S, Mannesse-Lazeroms SPG, Van Sterkenburg MAJA, Daha MR, Dijkman JH, Hiemstra PS. Effect of defensins on IL-8 synthesis in airway epithelial cells. Am J Physiol (Lung Cell Mol Physiol) 1997; 272: L888L896.

87. Nahori MA, Renesto P, Vargaftig BB, Chignard M. Activation and damage to cultured airway epithelial cells by human elastase and cathepsin G. Eur J Pharmacol 1992; 228: 213-218.

88. Abbinante-Nissen JM, Simpson LG, Leikauf GD. Neutrophil elastase increases secretory leukocyte protease inhibitor transcript levels in airway epithelial cells. Am J Physiol (Lung Cell Mol Physiol) 1993; 265: L286-L292.

89. Sallenave JM, Shulmann J, Crossley J, Jordana M, Gauldie J. Regulation of secretory leukocyte proteinase inhibitor (SLPI) and elastase-specific inhibitor (ESI/elafin) in human airway epithelial cells by cytokines and neutrophilic enzymes. Am J Respir Cell Mol Biol 1994; 11: 733-741.

90. Ballieux BEPB. Hiemstra PS, Klar-Mohamad N, et al. Detachment and cytolysis of human endothelial cells by proteinase 3. Eur J Immunol 1994; 24: 3211-3215.

91. Yang JJ, Kettritz R, Falk RJ, Jenette JC, Gaido ML. Apoptosis of endothelial cells induced by the neutrophil serine proteinases proteinase 3 and elastase. Am J Pathol 1996; 149: 1617-1626.

92. Boudier C, Holle C, Bieth JG. Stimulation of the elastolytic activity of leukocyte elastase by leukocyte cathepsin G. J Biol Chem 1981; 256: 10256-10258.

93. Cassatella MA. The production of cytokines by polymorphonuclear neutrophils. Immunol Today 1995; 16: 21-26.

94. Pang G, Ortega M, Zighang R, Reeves G, Clancy R. Autocrine modulation of IL- 8 production by sputum neutrophils in chronic bronchial sepsis. Am J Respir Crit Care Med 1997; 155: 726-731.

95. Banda MJ, Rice AG, Griffin GL, Senior RM. The inhibitory complex of human $\alpha 1$-proteinase inhibitor and human leukocyte elastase is a neutrophil chemoattractant. J Exp Med 1988; 167: 1608-1615.

96. Leavell KJ, Peterson MW, Gross TJ. The role of fibrin degradation products in neutrophil recruitment to the lung. Am J Respir Cell Mol Biol 1996; 14: 53-60.

97. Berger SP, Seelen MAJ, Hiemstra PS, et al. Proteinase 3, the major autoantigen of Wegener's granulomatosis, enhances IL-8 production by endothelial cells in vitro. $J$ Am Soc Nephrol 1996; 7: 694-701.

98. McElvaney NG, Nakamura H, Birrer P, et al. Modulation of airway inflammation in cystic fibrosis. In vivo suppression of interleukin- 8 levels on the respiratory epithelial surface by aerolization of recombinant secretory leukoprotease inhibitor. J Clin Invest 1992; 90: 1296-1301.

99. Hiemstra PS, Van Wetering S, Mannesse-Lazeroms SPG, Dijkman JH. Dexamethasone inhibits defensin-induced chemokine synthesis in airway epithelial cells in vitro. $J$ Leukoc Biol 1996; (Suppl.): 22 (Abstract).

100. Shibata Y, Nakamura H, Kato S, Tomoike H. Cellular detachment and deformation induce IL-8 gene expression in human bronchial epithelial cells. J Immunol 1996; 156: 772-777.

101. Simpson LG, Leikauf GD. Airway epithelial response to neutrophil elastase is mediated by protein kinase $\mathrm{C}$ and tyrosine kinase. Am J Respir Crit Care Med 1997; 135: A656 (Abstract).

102. Sommerhoff CP, Fang KC, Nadel JA, Caughey GH. Classical second messengers are not involved in proteinase-induced degranulation of airway gland cells. Am J Physiol 1996; 271: L796-L803.

103. Kagan BL, Selsted ME, Ganz T, Lehrer RI. Antimicrobial defensin peptides form voltage-dependent ion-permeable channels in planar lipid bilayer membranes. Proc Natl Acad Sci USA 1990: 87: 210-214. 